\title{
Idiopathic granulomatous mastitis-utility of fine needle aspiration cytology (FNAC) in preventing unnecessary surgery
}

\section{Idiyopatik granulomatöz mastitde gereksiz cerrahi girişimi önlemek için ince iğne aspirasyon sitolojisinin (IIAS) kullanılması}

\author{
Mimi Gangopadhyay ${ }^{1}$, Anuradha De ${ }^{1}$, Indranil Chakrabarti' ${ }^{1}$ Sailesh Ray², Amita Giri', Rinki Das ${ }^{3}$ \\ ${ }^{1}$ Department of Pathology, North Bengal Medical College \& Hospital, Sushrutanagar, Darjeeling, India \\ ${ }^{2}$ Department of Gyneclogy \& Obstetrics, North Bengal Medical College \& Hospital, Sushrutanagar, Darjeeling, India \\ ${ }^{3}$ Department of Surgery, North Bengal Medical College \& Hospital, Sushrutanagar, Darjeeling, India
}

\section{Abstract}

O bjective: Granulomatous mastitis is a benign disorder which closely mimics malignancy clinico-radiologically. A simple and cost effective modality like fine needle aspiration cytology (FNAC) can help in prompt diagnosis and avoid unnecessary surgery.

M aterial and M ethods: A retrospective study where data were collected for granulomatous lesions of the breast diagnosed by histopathology in a five year period and review of FNAC slides. Cases positive for Mycobacterium tuberculosis either on ZN stain or Polymerase chain reaction (PCR) and fungus were excluded. A total of 8 cases were included in our study for analysis.

R esults: All the cases showed the presence of granuloma composed of epithelioid histiocytes against a background of giant cells, polymorphs with absence of necrosis.

Conclusion: Cytological diagnosis of granulomatous mastitis is difficult as it overlaps with other etiologies like tuberculosis which is prevalent in this part of the world. However, with the use of ancillary techniques like PCR and negative microbiological investigations, a definitive diagnosis can be made.

(J Turkish-German Gynecol Assoc 2010; 11: 127-30)

Key words: Granulomatous mastitis, fine needle aspiration cytology (FNAC)

Received: 14 May, 2010

Accepted: 12 August, 2010
Özet

Amaç: Granülomatöz mastit klinik ve radyolojik olarak kanseri taklit edebilen iyi huylu bir hastalıktr. Basit ve ucuz bir yöntem olan ince iğne aspirasyon sitolojisi (iiAS) gereksiz cerrahileri önlemede ve kesin tanı koymada etkin bir yoldur.

Gereç ve Yöntemler: Bu retrospektif çalışma datalan 5 yıllık süre ile histopatolojik olarak granulomatöz lezyon tanısı konan hastalann İ̈AS lamlan ve kayitlan gözden geçirelerek toplanmıştr. ZN boyama veya PCR ile tanısı konmuş olan tüberküloz vakalan ve mantar enfeksiyonu olanlar çalışmaya alınmamıştır. toplam çalışmaya uygun 8 vaka incelenmiştir.

Bulgular: Tüm olgular epiteloid histiositler ve tabanda dev hücreler ve nekrozsuz polimorfmlar göstermiştir.

Sonuç: Granulomatoz mastitin sitolojik tanısı özellikle dünyanın bu bölgesinde olduğu gibi yaygin görülen tüberküloz varlı̆̆ında oldukça zor konulur. Ancak PCR ve negatif mikrobiolojik araştrmalar sayesinde ayıncı taniya kolayca gidilir.

(J Turkish-German Gynecol Assoc 2010; 11: 127-30)

Anahtar kelimeler: Granulomatöz mastit, ince iğne aspirasyon sitolojisi (IїAS)

Geliş Tarihi: 14 Mays 2010

Kabul Tarihi: 12 Ağustos, 2010

\section{Introduction}

Idiopathic granulomatous mastitis is a rare benign breast disease, first described by Kessler and Wallooch (1) in 1972. In the literature, only a few large series have been reported, emphasizing the histological (2-5), imaging (6-8) and cytological (9-11) aspects, with series sizes ranging from 6-16 cases. The histological features of granulomatous mastitis have been well described as consisting of non-caseating granulomas within the breast parenchyma and lobulitis with or without neutrophilic micro abscesses $(12,13)$. However, cytological features have not been widely discussed.

The clinical and radiological presentation mimics carcinoma, often resulting in unnecessary radical surgery. Therefore, in

our study we present eight cases of granulomatous mastitis with special emphasis on their cytological features.

With the increasing use of fine needle aspiration and cytology (FNAC) as the initial investigation for breast lesions, there is a need for an increased awareness of this disease entity so that prompt and correct line of management can be selected.

\section{Material and Methods}

The histopathology records of a tertiary care hospital were collected for cases of granulomatous lesion reported between July 2004 and J uly 2009. The histopathology slides and all the case histories of these patients were retrieved and re-analyzed. A total of 19 cases of granulomatous lesions of breast 
were diagnosed on histopathology during this period. Of these, FNAC slides of 14 patients could be retrieved. Among the latter, acid fast bacilli (AFB) were detected in Ziehl Neelsen (ZN) stained smear in one case only in which a straightforward diagnosis of tuberculosis of breast was made. In the remaining 13 cases, Polymerase chain reaction (PCR) was performed for the IS6110 sequence of mycobacterium tuberculosis either on material obtained on cytology or from paraffin-wax embedded material. PCR gave positive results in 5 cases and negative in the 8 cases. These PCR-negative cases gave negative results on Periodic Acid Schiff (PAS) and Grocott's Methanamine Silver staining and culture in Lowenstein-Jensen (LJ) media. These cases are included in our report of Idiopathic Granulomatous Mastitis.

(The FNAC were performed by trained and experienced pathologists using $10 \mathrm{ml}$ syringes fitted to a FNAC gun and using 22 to 23 gauge needles. The aspirated material was used to make direct smears for May Grunwald Giemsa (MGG) stain and alcohol-fixed smears for Haematoxylin and Eosin stain and/or Papanicolaou stains.

In all the cases, the following cytological parameters were evaluated-

a) Presence or absence of granulomas

b) Relative proportions of other cells like epithelioid histiocytes, lymphocytes, plasma cells and polymorphs.

c) Presence or absence of background necrosis

d) Multinucleated giant cells- proportion and morphology

e) Ductal cells- normal or atypical.

All the histopathological slides were reviewed and the diagnosis confirmed.

\section{Results}

All the patients were women and the mean age was 34.8 years. In 6 cases, the lesion was located on the left side and in the other 2 on the right (Table 1 ). At least 4 smears were prepared from each case and were stained with $\mathrm{H} \& \mathrm{E}$ and/or Papanicolaou stain, MGG, PAS and Grocott's Methanamine Silver stains.

All the 8 cases showed the presence of granulomas and giant cells in the smears (Fig. 1). The granulomas (Fig. 2) were composed of epithelioid histiocytes with abundant cytoplasm, oval to reniform nuclei, dispersed chromatin and conspicuous nucleoli. Background of all the smears showed epithelioid histiocytes with morphology similar to those seen constituting the granulomas. Polymorphs accounted for most of the inflammatory cells in all the cases. Three cases showed lymphocytes, while plasma cells were present in only one case. Caseous necrosis was absent in all the cases. The giant cells were both foreign body type and Langhan's type morphologically.

All the slides were negative for fungus on PAS stain and Grocott's Methanamine Silver stain. Culture did not yield any growth in any of the 8 cases. For all the cases, ZN stain staining for acid fast bacilli was non-contributory and Mycobacterium Tuberculosis DNA was not detected by PCR in the specimens (Fig. 3).

Histological review of all the cases confirmed the diagnosis of granulomatous mastitis (Fig. 4).

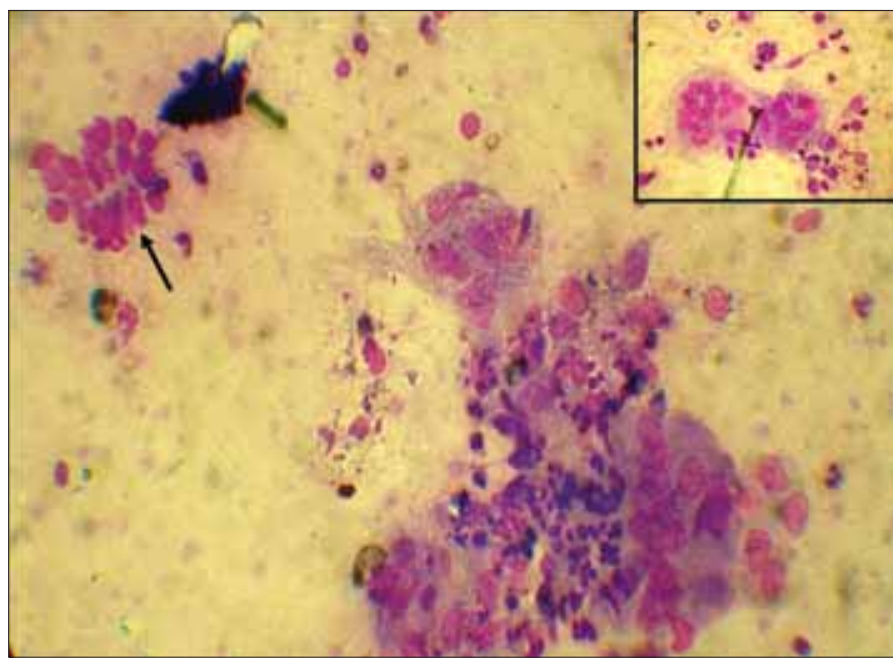

Figure 1. Collection of histiocytes, arrow $(\uparrow)$ showing benign ductal epithelial cells, inset showing giant cells. M G G, × 40

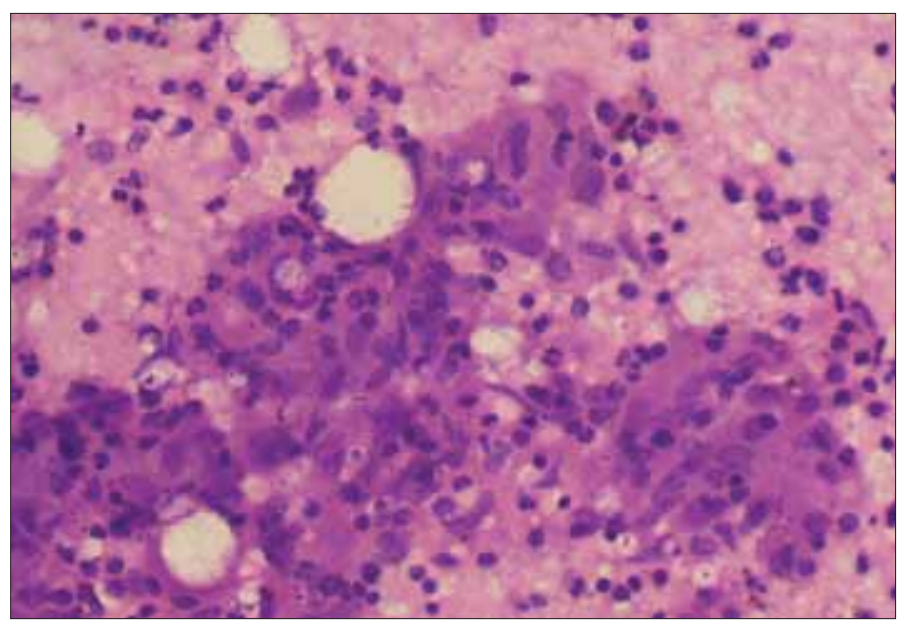

Figure 2. Granuloma comprising of epithelioid histiocytes with polymorphs in the background. $H \& E, \times 40$

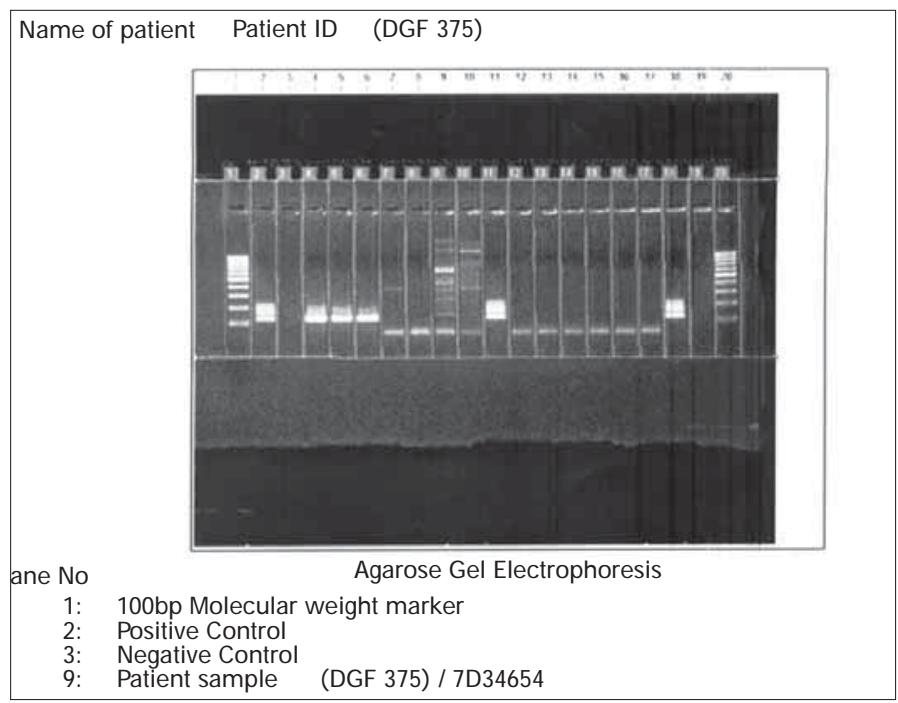

Figure 3. Photograph of agarose gel electrophoresis showing negative result for the sequence of Mycobacterium tuberculosis 


\section{Discussion}

Granulomatous mastitis is an uncommon breast lesion that is well known for its worrisome clinical presentation, particularly

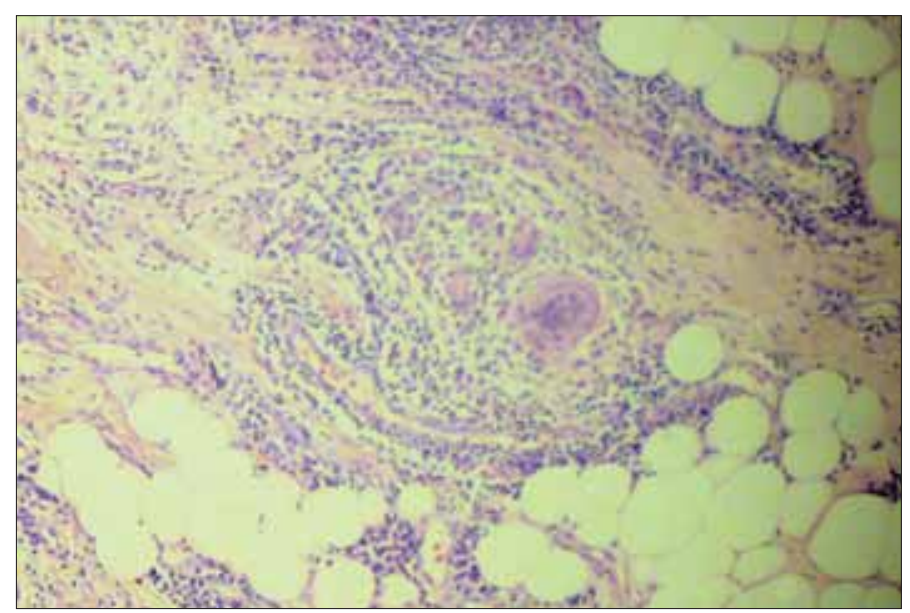

Figure 4. H istopathology section showing granuloma, giant cells \& polymorphs involving breast lobule. H\&E, x 40 in younger women (14). In our study, however, one patient was aged 61 years. Clinically and radiologically, granulomatous mastitis is difficult to distinguish from breast carcinoma (14). In our study, the radiological diagnoses of cases 1 and 7 were that of breast carcinoma and both patients had to undergo unnecessary mastectomy. This could have been avoided by performing core biopsy before mastectomy (15).

The etiology of idiopathic granulomatous mastitis is still unknown. Kessler and Wallooch proposed an autoimmune pathogenesis (1). In a recently reported case, immunohistochemical staining showed that the lesion contained predominantly stromal T lymphocytes (16). However, there has been no evidence of systemic immune abnormalities such as the formation of autoantibodies or antigen-antibody complexes.

Among the only three large series describing the FNAC features of granulomatous mastitis in the literature, the usefulness of FNAC in granulomatous mastitis has been debated, with some authors confirming the useful role of $\operatorname{FNAC}(10,11)$, whereas others have concluded that the various causes of granulomatous inflammation cannot be confidently differentiated by FNAC (9). The presence of epithelioid histiocytes appears to be a common feature, having been reported in all cases of granuloma-

Table 1. Clinicopathological profile of patients included in the study

\begin{tabular}{|c|c|c|c|c|c|c|}
\hline $\begin{array}{l}\text { Case } \\
\text { Number }\end{array}$ & Age & Sex & Clinical Features & Radiology & FNAC diagnosis & $\begin{array}{l}\text { Histopathological } \\
\text { diagnosis }\end{array}$ \\
\hline 1 & 30 & $\mathrm{~F}$ & $\begin{array}{l}\text { Lump in left upper outer } \\
\text { quadrant breast with axillary } \\
\text { lymphadenopathy }\end{array}$ & $\begin{array}{l}\text { Mass with angulated and } \\
\text { spiculated margins } \\
\text { surrounded by echogenic } \\
\text { fibrous tissue } \\
\text { ? Carcinoma }\end{array}$ & $\begin{array}{l}\text { Granulomatous } \\
\text { Mastitis }\end{array}$ & $\begin{array}{l}\text { Idiopathic } \\
\text { Granulomatous } \\
\text { Mastitis }\end{array}$ \\
\hline 2 & 28 & $\mathrm{~F}$ & $\begin{array}{l}\text { Lump in right upper inner } \\
\text { quadrant breast }\end{array}$ & NotDone & $\begin{array}{l}\text { Granulomatous } \\
\text { Mastitis }\end{array}$ & $\begin{array}{l}\text { Idiopathic } \\
\text { Granulomatous } \\
\text { Mastitis }\end{array}$ \\
\hline 3 & 25 & $\mathrm{~F}$ & $\begin{array}{l}\text { Lump in left breastinvolving } \\
\text { three-fourth of breast with } \\
\text { sinus formation and few } \\
\text { enlarged axillary lymph nodes }\end{array}$ & $\begin{array}{l}\text { Increased soft tissue } \\
\text { thickening and edema } \\
\text { with multiple focal } \\
\text { heterogenous area. } \\
\text { ? Inflammatory }\end{array}$ & $\begin{array}{l}\text { Granulomatous } \\
\text { Mastitis }\end{array}$ & $\begin{array}{l}\text { Idiopathic } \\
\text { Granulomatous } \\
\text { Mastitis }\end{array}$ \\
\hline 4 & 61 & $\mathrm{~F}$ & $\begin{array}{l}\text { Right breast lump and } \\
\text { nipple discharge }\end{array}$ & NotDone & $\begin{array}{l}\text { Granulomatous } \\
\text { Mastitis }\end{array}$ & $\begin{array}{l}\text { Idiopathic } \\
\text { Granulomatous } \\
\text { Mastitis }\end{array}$ \\
\hline 5 & 35 & $\mathrm{~F}$ & Left breast lump & NotDone & $\begin{array}{l}\text { Granulomatous } \\
\text { Mastitis }\end{array}$ & $\begin{array}{l}\text { Idiopathic } \\
\text { Granulomatous } \\
\text { Mastitis }\end{array}$ \\
\hline 6 & 36 & $\mathrm{~F}$ & $\begin{array}{l}\text { Pain and ill defined lump in } \\
\text { right breast }\end{array}$ & Benign breastdisease & $\begin{array}{l}\text { Granulomatous } \\
\text { Mastitis }\end{array}$ & $\begin{array}{l}\text { Idiopathic } \\
\text { Granulomatous } \\
\text { Mastitis }\end{array}$ \\
\hline 7 & 32 & $\mathrm{~F}$ & $\begin{array}{l}\text { Lump in left breast with } \\
\text { sinus formation }\end{array}$ & $\begin{array}{l}\text { heterogeneous, with a } \\
\text { thin rim of subcapsular } \\
\text { radiolucent fat }\end{array}$ & $\begin{array}{l}\text { Granulomatous } \\
\text { Mastitis }\end{array}$ & $\begin{array}{l}\text { Idiopathic } \\
\text { Granulomatous } \\
\text { Mastitis }\end{array}$ \\
\hline 8 & 32 & $\mathrm{~F}$ & Lump in left breast & $\begin{array}{l}\text { spiculated margins with } \\
\text { separate anterior focal } \\
\text { asymmetry } \\
\text { ? Carcinoma }\end{array}$ & $\begin{array}{l}\text { Granulomatous } \\
\text { Mastitis }\end{array}$ & $\begin{array}{l}\text { Idiopathic } \\
\text { Granulomatous } \\
\text { Mastitis }\end{array}$ \\
\hline
\end{tabular}


tous mastitis in the literature $(9-11,14,16,17)$. In our study, all the cases showed epithelioid histiocytes whether single or in the form of granulomas.

The number of single epithelioid histiocytes was directly proportional to the number of granulomas in the smears. Our series showed the predominance of neutrophils over lymphocytes, similar to that of another study of nine cases, which demonstrated moderate to abundant numbers of neutrophils in the FNAC preparation. Most other reports have described a mixed inflammatory cell infiltrate. Another characteristic feature was the absence of caseous necrosis, which favors a diagnosis of granulomatous mastitis over an infective cause of granulomatous inflammation.

The single most important differential diagnosis of granulomatous mastitis in our part of the world is tuberculosis. The predominant presence of neutrophils in the background and the lack of caseous necrosis favor a diagnosis of granulomatous mastitis rather than tuberculosis (14). Granulomatous mastitis should also be distinguished from other chronic inflammatory breast diseases such as mammary duct ectasia, Wegener's granulomatosis, sarcoidosis and histoplasmosis (17). A diagnosis of granulomatous mastitis should also be considered when high numbers of epithelioid histiocytes are seen in smears, even in the absence of granulomas.

\section{Conflict of interest}

None declared.

\section{References}

1. Kessler E, Wallooch Y. Granulomatous mastitis: a lesion clinically simulating carcinoma. Am J Clin Pathol 1972; 58: 642-6.

2. Fletcher A, Magrath IM, Riddell RH, Talbot IC.. Granulomatous mastitis : a report of seven cases. J Clin Pathol 1982; 35: 941-5.

3. Going JJ, Anderson TJ, Wilkinson S, Chetty U. Granulomatous lobular mastitis. J Clin Pathol 1987; 40: 535-40.
4. Galea MH, Robertson J F, Ellis IO, Elston CW, Blamey RW.. Granulomatous lobular mastitis. Aust N ZJ Surg 1989; 59: 547-50.

5. Bhaskaran CS, Prasad KR, Rao G, Kameshwari R, Saheb DA, Aruna CA. Chronic granulomatous mastitis:review of 26 cases with special reference to chronic lobular mastitis. Indian J Pathol Microbiol 1992; 35: 38-43.

6. Engin G, Acunas G, Acunas B. Granulomatous mastitis: gray scale and color Doppler sonographic findings. J Clin Ultrasound 1999; 27: 101-6.

7. Han BK, Choe YH, Park J M, Moon WK, Ko YH, Yang JH, et al. Granulomatous mastitis : mammographic and sonographic appearances. Am J Roentgenol 1999; 173: 317-20.

8. Yilmaz E, Lebe B, Usal C, Balci P. Mammographic and sonographic findings in the diagnosis of idiopathic granulomatous mastitis. Eur Radiol 2001; 11: 2236-40.

9. Martinez-Parra D, Nevado-Santos M, Melendez-Guerrero B, GarcíaSolano J, Hierro-Guilmain CC, Pérez-Guillermo M. Utility of fineneedle aspiration in the diagnosis of granulomatous lesions of the breast. Diagn Cytopathol 1997; 17: 108-14.

10. Kumarasinghe MP. Cytology of granulomatous mastitis. Acta Cytol 1997; 41: 727-30.

11. Yip $\mathrm{CH}$, Jayaram $\mathrm{G}$, Swain $\mathrm{M}$. The value of cytology in granulomatous mastitis: a report of 16 cases from Malayasia. Aust N ZJ Surg 2000; 70: 103-5.

12. Page DL, Anderson TJ . Diagnostic histopathology of the breast. Edinburgh: Churchill Livingstone, 1987.

13. Ellis IO, Elston CW, Goulding H. Inflammatory conditions. In: Elston CW, Ellis IO, eds. Systemic Pathology, Vol.13, 3rd ed. The Breast. Edinburgh: Churchill Livingstone, 2000: 192-5.

14. Tse GMK, Poon CSP,Law BKB, Pang LM, Chu WCW, Ma TKF. Fine needle aspiration cytology of granulomatous mastitis. J Clin Pathol 2003; 56: 519-21.

15. Hirata S, Saito T, Kiyanagi K, Kitada M, Yamazaki K, Sasajima T et al. Granulomatous mastitis diagnosed by core-needle biopsy and successfully treated with corticosteroid therapy: a case report. Breast Cancer. 2003; 10: 378-81.

16. Miliauskas JR, Pieterse AS, Williams RS. Granulomatous lobular Mastitis. Aust NZJ Surg 1995; 65: 139-41.

17. Imoto S, Kitaya T, Kodama T, Hasebe T, Mukai K. Idiopathic Granulomatous Mastitis: Case Report and Review of the Literature. Japanese J ournal of Clinical Oncology, 1997; 27: 274-7. 